\title{
ДОМАШНИЙ АРЕСТ КАК МЕРА ПРЕСЕЧЕНИЯ В РОССИЙСКОМ УГОЛОВНОМ СУДОПРОИЗВОДСТВЕ
}

\section{HOUSE ARREST AS A PREVENTIVE MEASURE IN RUSSIAN CRIMINAL PROCEEDINGS}

\section{Firsov}

Summary. In the article the analysis of house arrest es a preventive measure to find out its criminal procedural nature and the essence of this preventive measure. At the same time, the essential features of house arrest are highlighted: purpose, restrictions and prohibitions, imposed on suspects, accused persons and entities eligible to elect a preventive measure. In addition, the article analyzes the definitions of house arrest given by different authors. As a result of studying the essential features of house arrest, the definition of this measure of restraint is given.

Keywords: a preventive measure, house arrest, basis, essential features, restrictions and prohibitions.
Фирсов Владимир Григорьевич

Независимый исследователь firsov_vg65@mail.ru

Аннотация. В статье проведен анализ домашнего ареста как меры пресечения для выяснения его уголовно-процессуальной природы и существа данной меры пресечения. При этом выделены существенные признаки домашнего ареста: цель, ограничения и запреты, налагаемые на подозреваемого, обвиняемого, субъекты, правомочные избирать меры пресечения. Кроме того, в статье проанализированы определения домашнего ареста, данные разными авторами. В результате изучения существенных признаков домашнего ареста дано определение данной меры пресечения.

Ключевые слова: мера пресечения; домашний арест; основания; существенные признаки, ограничения и запреты.

применения данного института. Цели применения у разных мер пресечения различаются по степени их эффективности.

В настоящее время вопрос о целях избрания домашнего ареста - один из наиболее сложных в теории и на практике. В уголовно-процессуальном законодательстве они прямо не называются, недостаточно освещены и в юридической литературе.

По мнению Б.Б.Булатова, главная цель домашнего ареста - изоляция обвиняемого на дому и сведение к минимуму его контактов с внешним миром[1].

Ю. Г. Овчинников полагает, что целью домашнего ареста является «обеспечение надлежащего поведения подозреваемого, обвиняемого с оставлением их в условиях мягкой изоляции, т.е. с сохранением права проживать в собственном жилище, с применением определенных запретов.» [2].

Е.В. Салтыков исходит из того, что цель применения домашнего ареста - предотвратить совершение обвиняемым (подозреваемым) действий, указанных в ст. 97 УПК РФ на досудебной и судебных стадиях, а также для обеспечения исполнения приговора, путем установления ограничений, определенных в ст. 107 УПК РФ при наличии оснований, которые установлены для заключения 
под стражу, с учетом его возраста, состояния здоровья, семейного положения и других обстоятельств[3].

Цели домашнего ареста, как и других мер пресечения, взаимосвязаны с назначением уголовного судопроизводства. Без мер пресечения невозможно осуществление функций уголовного преследования, разрешения уголовного дела, а также гражданско-правовой функции. Если не обеспечить надлежащее поведение подозреваемого, обвиняемого, не пресечь его стремление скрыться, то невозможно будет реализовать указанные функции. Вместе с тем, с учетом особенностей данной меры пресечения, у домашнего ареста можно выделить цели, которые отличают его от целей иных мер пресечения.

Таким образом, в качестве цели домашнего ареста можно выделить обеспечение надлежащего поведения подозреваемого или обвиняемого в условиях изоляции от общества в жилом помещении, в котором он проживает, с применением определенных запретов.

Домашний арест - это мера пресечения, избираемая в период производства по уголовному делу к подозреваемому, обвиняемому. Термин «домашний» означает относящийся к "дому», под которым понимается жилое здание, строение или жилое помещение[4]. В соответствии с п. 10 ст. 5 УПК РФ, жилище - это индивидуальный жилой дом с входящими в него жилыми и нежилыми помещениями, жилое помещение независимо от формы собственности, входящее в жилищный фонд и используемое для постоянного или временного проживания, а равно иное помещение или строение, не входящее в жилищный фонд, но используемое для временного проживания. Согласно ст. 2 ст. 15 Жилищного кодекса РФ, жилым помещением признается изолированное помещение, которое является недвижимым имуществом и пригодном для постоянного проживания граждан (отвечает установленным санитарным и техническим правилам и нормам, иным требованиям законодательства).

Постановлением Пленума Верховного Суда РФ от 19 декабря 2013 г. № 41 дано разъяснение в п. 38, согласно которому под жилым помещением для целей статьи 107 УПК РФ понимается любое жилое помещение независимо от формы собственности, входящее в жилищный фонд и используемое для постоянного или временного проживания, а равно иное помещение или строение, не входящее в жилищный фонд, но используемое для проживания (например, дача), если оно отвечает требованиям, предъявляемым к жилым помещениям[5].

Уголовно-процессуальная характеристика домашнего ареста как меры пресечения связана с ограничениями прав и свобод обвиняемых (подозреваемых), а именно:
- на свободу и личную неприкосновенность (ч. 1 ст. 22 Конституции РФ);

- свободно передвигаться, выбирать место пребывания и жительства (ч. 1 ст. 27 Конституции РФ);

- свободно выезжать за пределы Российской Федерации (ч. 2 ст. 27 Конституции РФ);

- собираться мирно, без оружия, проводить собрания, митинги и демонстрации, шествия и пикетирование (ст. 31 Конституции РФ);

- на равный доступ к государственной службе (ч. 4 ст. 32 Конституции РФ);

- на свободное использование своих способностей и имущества для предпринимательской и иной не запрещенной законом экономической деятельности (ч. 1 ст. 34 Конституции РФ);

- свободно распоряжаться своими способностями к труду, выбирать род деятельности и профессию (ч. 1 ст. 37 Конституции РФ);

- на заботу о детях, их воспитание (ч. 2 ст. 38 Конституции РФ);

- на образование (ч. 1 ст. 43 Конституции РФ);

- литературного, художественного, научного, технического и других видов творчества, преподавания (ч. 1 ст. 44 Конституции РФ);

- на участие в культурной жизни и пользование учреждениями культуры, на доступ к культурным ценностям (ч. 2 ст. 44 Конституции РФ).

Домашний арест существенно ограничивает конституционные права и свободы гражданина, уступая по степени их ограничения только такой мере пресечения, как заключение под стражу. Указанный объем ограничений прав и свобод показывает достаточно высокий и строгий уровень ограничений при применении меры пресечения в виде домашнего ареста, являющейся по строгости следующей мерой пресечения после заключения под стражу. Это диктует необходимость подробного, детального нормативного регулирования применения данной меры пресечения, вплоть до принятия отдельного закона, аналогичного Федеральному закону от 15 июля 1995 г. № 103-Ф3 «О содержании под стражей подозреваемых и обвиняемых в совершении преступлений».

В большинстве определений домашнего ареста, содержащихся в литературе, отсутствует указание на такие его существенные признаки, как цель, основания применения.

Так, В.А. Светочев определяет домашний арест следующим образом: «сущность домашнего ареста заключается в ограничении прав и свобод обвиняемого (в исключительных случаях подозреваемого) посредством судебного установления ограничений и запретов, связанных со свободою передвижения, когда полная 
изоляция лица не вызвана необходимостью, общением с определенными лицами, получением и отправлением корреспонденции, ведением переговоров с использованием любых средств связи, с учетом его возраста, состояния здоровья, семейного положения и других обстоятельств.» [6].

Г.С. Русман понимает под домашним арестом ограничение свободы подозреваемого, обвиняемого в виде полной или частичной изоляции его от общества с установлением запретов на общение, предусмотренных УПК РФ[7].

По мнению О.И. Цоколовой, домашний арест - это мера пресечения, состоящая в ограничении свободы передвижения обвиняемого и запрете на общение и переговоры с другими лицами[8].

Ю.Г. Овчинников под домашним арестом понимает меру процессуального принуждения, избираемую по решению суда в судебном заседании по делам о преступлениях, за которые законом предусмотрено наказание в виде лишения свободы на срок свыше двух лет, в отношении обвиняемого, в исключительных случаях - подозреваемого, оказывающая воздействие путем существенного ограничения личной свободы (с сохранением права проживать в его жилище) и возложения запретов общаться с определенными лицами, получать и отправлять корреспонденцию, вести переговоры с использованием любых средств связи[2].

В определении домашнего ареста, данным Е.В. Салтыковым, содержатся все существенные признаки данной меры пресечения, за исключением цели применения. В соответствии с ним домашний арест - это мера пресечения, позволяющая, при наличии оснований для избрания содержания под стражей и с учетом возраста, состояния здоровья, семейного положения обвиняемого (подозреваемого) и других обстоятельств, применить к нему по постановлению суда ограничения, связанные со свободой передвижения, а также установить запрет на общение с определенными лицами, получение и отправление корреспонденции, ведение переговоров с использованием средств связи[3].
Из содержания ст. 107 УПК РФ следует, что домашний арест избирается по судебному решению и заключается в нахождении подозреваемого или обвиняемого в изоляции от общества в жилом помещении, в котором он проживает, с возможным возложением запретов общаться с определенными лицами, отправлять и получать почтово-телеграфные отправления, использовать средства связи и информационно-телекоммуникационную сеть «Интернет».

Конституционный Суд РФ указал, что мера пресечения в виде домашнего ареста заключается в ограничениях, связанных со свободой передвижения подозреваемого, обвиняемого, а также в запрете общаться с определенными лицами, получать и отправлять корреспонденцию и вести переговоры с использованием любых средств связи; эта мера избирается по решению суда при наличии оснований и в порядке, которые установлены статьей 108 «Заключение под стражу» УПК РФ, с учетом возраста подозреваемого, обвиняемого, его состояния здоровья, семейного положения и других обстоятельств (часть вторая); в постановлении или определении суда об избрании домашнего ареста в качестве меры пресечения указываются конкретные ограничения, которым подвергается подозреваемый, обвиняемый, а также указываются орган или должностное лицо, на которые возлагается осуществление надзора за соблюдением установленных ограничений[9].

Таким образом, в результате анализа существенных признаков данной меры пресечения, а также теоретических и законодательных положений, можно сделать вывод, что домашний арест - мера пресечения, избираемая по решению суда в отношении обвиняемого (подозреваемого) в целях обеспечения надлежащего поведения подозреваемого или обвиняемого в условиях изоляции от общества, при наличии предусмотренных законом оснований, с учетом возраста, состояния здоровья, семейного положения и других обстоятельств, заключающаяся в ограничении свободы его передвижения путем изоляции в пригодном для проживания жилище и возможным установлением судом запретов общаться с определенными лицами; отправлять и получать почтово-телеграфные отправления; использовать средства связи и информационно-телекоммуникационную сеть «Интернет».

\section{ЛИТЕРАТУРА}

1. Булатов Б. Б. Государственное принуждение в уголовном судопроизводстве: Монография. Омск: Омская Академия МВД России, 2003. С. 98.

2. Овчинников Ю. Г. Домашний арест как мера пресечения в уголовном процессе: дис. . .. канд. юрид. наук. Омск, 2006. С. 23.

3. Салтыков Е. В. Домашний арест в российском уголовном процессе: дис. ... канд. юрид. наук, Екатеринбург, 2007. С. 79.

4. Ожегов С. И. Словарь русского языка. 2-е изд. Под общ. ред. академика Обнорского С. П. Гос. изд. иностранных и национальных словарей. М., 1952. С. 148.

5. Постановление пленума Верховного Суда РФ от 19 декабря 2013 г. № 41 «0 практике применения судами законодательства о мерах пресечения в виде заключения под стражу, домашнего ареста и залога». // Российская газета. 27 декабря 2013 г. 
6. Светочев В. А. Домашний арест как мера пресечения в уголовном процессе Российской Федерации: дис. ... канд. юрид. наук, Калининград, 2009. С. 68.

7. Русман Г.С. Судебный контроль за избранием мер пресечения в виде заключения под стражу, домашнего ареста: дис. ... канд. юрид. наук Челябинск, 2006. C. 151.

8. Ц Цоколова О. И. Комментарий к Уголовно-процессуальному кодексу Российской Федерации (постатейный) / под общ. ред. В. И. Радченко. М. ЗАО «Юридический дом «Юстицинформ», 2003. С. 239.

9. Постановление Конституционного Суда РФ от 06.12.2011 № 27-П «По делу о проверке конституционности статьи 107 Уголовно-процессуального кодекса Российской Федерации в связи с жалобой гражданина Эстонской Республики А. Т. Федина». Собрание законодательства Российской Федерации, № 51, 19.12.2011, ст. 7552.

( Ф Фирсов Владимир Григорьевич ( firsov_vg65@mail.ru ).

Журнал «Современная наука: актуальные проблемы теории и практики» 